\title{
The Impact of the Formation of Malaysia 16 September 1963: A Historical Highlight
}

\section{| Ayu Nor Azilah Mohamad ${ }^{1}$ | Wayu Nor Asikin Mohamad ${ }^{2}$ | |Abdul Razak Salleh ${ }^{3}$ | Mohamed Ali Haniffa ${ }^{4}$ |}

${ }^{1}$ Kolej Universiti Islam Antarabangsa Selangor, Selangor, Malaysia

2,3 University College Bestari, Terengganu, Malaysia

${ }^{4}$ Universiti Utara Malaysia, Malaysia

1ayunorazilah@kuis.edu.my ${ }^{2}$ wayu@ucbestari.edu.my

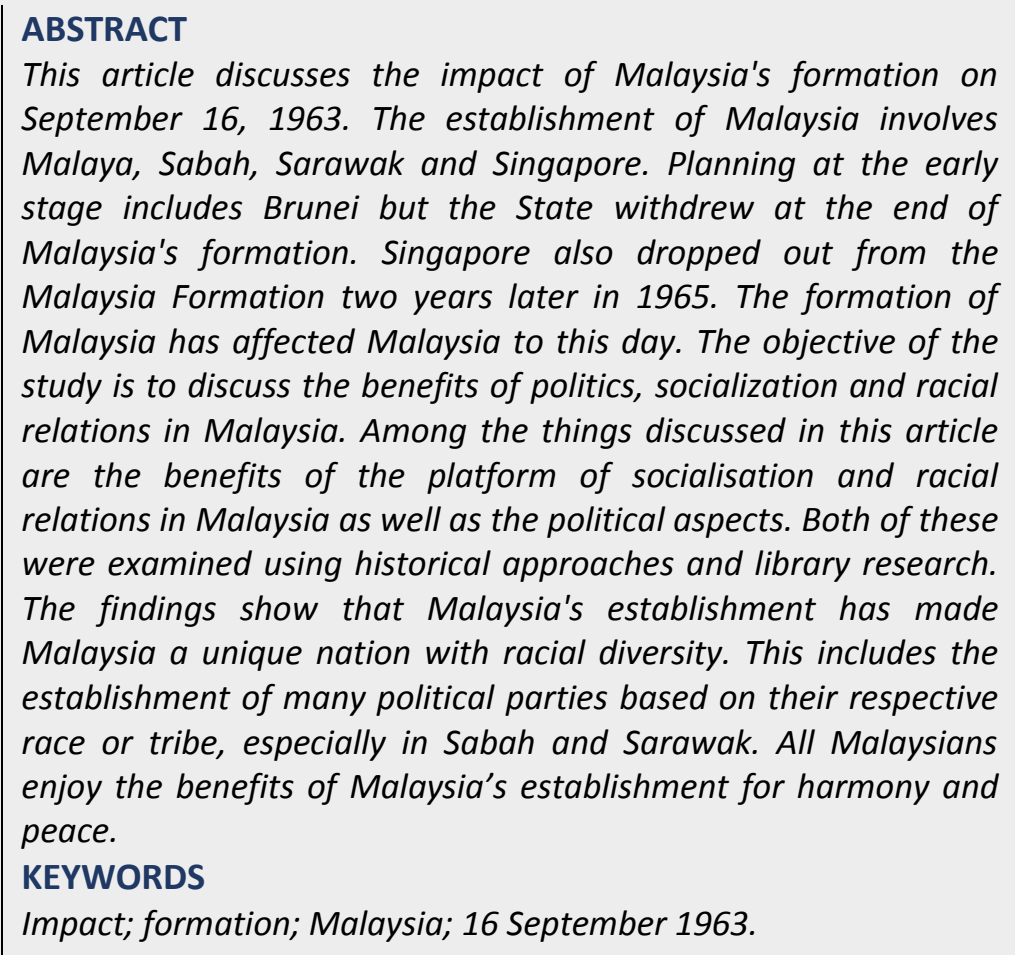

\section{INTRODUCTION}

The formation of Malaysia dated 16 September 1963 was through a long historical process for the interest of all parties. The September 16, 1963 incident involves the collaboration between Malaya, North Borneo (Sabah), Sarawak and Singapore. However, Singapore opted out of Malaysia in 1965. According to Tunku Abdul Rahman Putra al-Haj, Malaysia's need for the establishment of a large federation by the merger of the Federation of Malaya, North Borneo (Sabah), Sarawak, Singapore and Brunei into a single political and economic entity was in the common interest of all parties concerned. However, this article is more focused on the benefits of socialisation and racial relations in Malaysia as well as the political aspects of Malaysia's Formation on September 16, 1963.

\section{RESEARCH METHODS}

This article uses historical approaches as well as bibliography studies. The historical approach was used to look at the exact facts from political aspects in the discussion of the impact of the formation of Malaysia on 16 September 1963.

Among the books that has been used for this study is 'Duri Dalam Daging' by Nik Anuar Nik Mahmud (2001), published by the Malaysian Historical Society. This book is one of the evidences of the formation of Malaysia that includes Singapore in this coalition. 
This book provides a clear and comprehensive picture of the sequence of events that occurred in the mid-1960s.

Another reference book is 'Dasar British Terhadap Hubungan SingapuraMalaysia:1959-1969.' This book is written by Rozeman Abu Hassan (2016). This content of this book explains the British policy and needs towards the combination of Singapore and Malaysia.

\section{RESULT AND DISCUSSION}

\section{The History of the Formation of Malaysia 16 September 1963}

The idea of setting up Malaysia emerged in Malaya before the Second World War. The Malay Youth Union led by Ibrahim Haji Yaacob once aspired to combine the territories of the Malay Archipelago under the concept of Indonesia Raya or Greater Malay. This idea persisted after the Second World War when Dr. Burhanuddin Al-Helmi, who heads the Malay Malaya National Party, also has the same ambition. For that reason, when the Malayan Union Constitution was held in Malaya on April 1, 1946, the isolation of Singapore from Malaya had raised opposition from the general population of Malaya especially among the Malays (Kassim Thukiman, 2002: 173).

In addition, the initial idea of combining Malaya, Singapore and the region of Borneo began since the late 19th century. In 1959, the leader of the People's Action Party (PAP) in Singapore, Lee Kuan Yew suggested that Singapore be merged with Malaya as a step towards independence. Earlier, two previous Singaporean leaders, David Marshall and Lim Yew Hock had voiced similar suggestions. Lee Kuan Yew's proposal was rejected by Tunku Abdul Rahman because the 'marriage' was seen as a cause to social problems because of the uneven balance between the Malays and the Chinese (Roslan Zainuddin, 2005: 165). A small merger involving Singapore and Malaya also involved the threat to Malayan politics when a large number of Chinese societies in Singapore could threaten the Malay majority population that existed at that time. This kind of racial balance will be a sensitive issue to the Malay majority community with special previleges in the Federation of Malaya. In addition, it is also feared that the communist ideology in Singapore will easily spread to Malaya with this merger.

The idea of Malaysia's formation was triggered on May 27, 1961 through a speech made by Tunku Abdul Rahman, Prime Minister of the Federation of Malaya during the Foreign Correspondent Association of Southeast Asia conference in Singapore. In his speech, Tunku Abdul Rahman mooted the idea of creating a form of economic and political union involving the Federation of Malaya with the British colonies of Singapore, North Borneo (Sabah), Sarawak and Brunei.

'As a nation, Malaya today knows that it cannot stand and live alone. Outside of international politics, our national politics should be based on a broad concept. Later Malaya will be able to seek understanding with the British and the people of Singapore,

North Borneo, Brunei and Sarawak.' (Nik Anuar Nik Mahmud, 2001: 31)'

The idea was raised on the realisation that Malaya and the territories were difficult to stand alone and separated, especially in facing international competition. The proposal also calls for the need to cooperate between political, economic and social affiliates who are also willing to cooperate with the British government in promoting the formation of new political ideas in Southeast Asia.

This idea of Malaysia's formation has attracted the attention of journalists present during the day and has led to various positive and negative reactions in Southeast Asia, especially in the concerned areas. Newspapers throughout Southeast Asia were also debating on the same issue. Many claimed that the idea of Malaysia's formation by Tunku 
Abdul Rahman was in a hurry and too sudden without preparations, not knowing that before the announcement, Tunku Abdul Rahman had held numerous meetings with several key figures associated to the respective territories (Mardiana Nordin \& Hasnah Hussiin, 2014: 111). The meeting with Lee Kuan Yew in Singapore was held in January 1961, with Senu Abdul Rahman relating his observations in Sabah, Sarawak and Brunei in 1960 together with British Prime Minister Harold MacMillan in London in early 1961. This element proves that the merger proposals of the respective areas are expressed more clearly, with full commitment and far sighted (Mardiana Nordin \& Hasnah Hussiin, 2006: 63).

Looking at the factors that led to the existence of Malaysia, it is clear that the establishment of Malaysia is not solely due to the desires of the people of Malaya, Singapore and Borneo or Sarawak. There are other factors involved especially those in relation to the the British government wanting to decolonise its territories in Borneo and Singapore. At the same time, the Federal Government of Malaya has also observed that the movement and influence of communists in Singapore could threaten the security of the Federation of Malaya if it is not handled well (Ariffin Omar, 2007: 339).

For Muslim and socialist opposition politicians, Tunku Abdul Rahman's plan is just to hide the fact that the British will continue to dominate Southeast Asia through an evil imperial shift from 'divide and rule' to 'unite and rule'. Malaysia is seen as the best solution for British imperialism to retain its power over North Borneo's wealth ... and at the same time address the threats of the leftists in Singapore. 'The establishment of Malaysia was mainly driven by British economic interests. The formation of Malaysia proves to be a 'wise act' because this is the way in which the British will be able to save its investment by seemingly transferring power (Nicholas J. White, 2010: 34).

Subsequently, a memorandum was agreed to guarantee the rights and interests of the entire North Borneo and Sarawak communities. The memorandum of 20 is a memorandum signed by North Borneo to the Inter-governmental Committee established in August 1962. The committee was formed as a result of the Cobbold Commission's proposal and its main function was to ensure the rights and interests of the people of Sabah and Sarawak were retained after joining Malaysia. The committee is chaired by Lord Landsdowne and its members comprise representatives of the British government, Federation of Malaya, North Borneo and Sarawak (Special Article, 2018).

The purpose of this committee is to review and recommend the constitutional provisions relating to the entry of Sabah and Sarawak into the Federation of Malaysia. Through this committee, a memorandum entitled '20-Point Agreement' was sent by Sabah, among others, to protect Sabah's rights and interests within the Federation of Malaysia. Sarawak has agreed on the matters set out in the memorandum primarily involving the interests and rights of the people in general or the 18 Articles in Sarawak. As a result of the memorandum submitted, the Inter-governmental Committee recommended the following important points to be fulfilled and incorporated into the Federal Constitution. Tunku Abdul Rahman has insisted that the formation of the Malaysian Federation is not a new colony (Neo-colonialism) and the participation of the two Borneo provinces into the new Federation will accelerate the independence of the two provinces (A Rahman Tang Abdullah et.al, 2017 : 89).

\section{The Impact of Malaysian Society's Pluralisation}

The Formation of the Federation of Malaya comprising of the provinces of North Borneo (Sabah), Sarawak and Singapore is to safeguard the interests and position of the Bumiputeras. According to Tunku Abdul Rahman, the idea of forming Malaysia should 
combine the Borneo regions like Sabah, Sarawak and Brunei and not only limited to Malaya and Singapore alone. Elimination of Malay majority will happen if only Malaya and Singapore merges. This is because Singapore has 80 percent of non-Malays and when combined with the people of the Federation of Malaya, the non-Malays will be the largest community. When a merger occurs between Malaya and Singapore, the number of Chinese will be 43.5 per cent, while the Malays will be 43 per cent. This is because the estimated population of Malaya in the 1960s consists of about 50 per cent Malays and 36.9 per cent Chinese.

Thus, when the people of Sabah and Sarawak join this coalition, the number of indigenous peoples will be able to offset the Chinese. This has caused the Bumiputera in Sabah and Sarawak to feel offended as they are considered to be important only to offset the number of Chinese but their own interests and agreement to join the federation are ignored. The merger has made the number of Bumiputeras including the Malays to be 46.3 per cent, while the Chinese became 42.4 per cent. This acts as a means to secure the position of the Malays and Bumiputeras in order for them to not be threatened and allows the Malays and Bumiputeras to remain as the largest group.

To overcome the doubt of the Bumiputera society in Sabah and Sarawak, several concessions have been granted to them as enshrined in the Federal Constitution of Malaysia;

- Sabah and Sarawak are responsible for immigration matters including the entry of Malaysians from other states.

- Although the Malay language is the official language of the Federation, English shall continue as the medium of instruction in education and as the official language for the state government until the State Legislative Assembly changes this policy.

- Islam is accepted as an official religion but other religions can be spread in Sabah and Sarawak.

- The Sabah and Sarawak Bumiputeras will enjoy the same rights as Malays in Malaysia.

- Financial regulations will be provided to ensure that financial assistance from the federal government is obtained for the development of Sabah and Sarawak.

- A separate public administration system for both territories was formed so that foreign officials would remain until local officials could be trained to replace them (Ariffin Omar, 2007: 340).

The communication systems in both regions are also very poor and inefficient; its infrastructure is still dependent on rivers and air travel at that point. It is difficult to create massive land-based connectivity. In addition, the Bumiputeras of these two regions were also not well treated by the British government. Outsiders who come to this region were given more attention. Hence, the level of education, economic control, literacy rate and government posts are higher among outsiders. There are very few Bumiputeras who attain higher education and these factors limit their chances of holding any government posts (Mardiana Nordin \& Hasnah Hussin, 2006: 66).

When Malaysia was formed on 31 August 1963, people from Borneo would automatically be accepted as Malaysians and and so would be Singaporeans. On 18 July 1962, the North Borneo Executive Council unanimously agreed to the need for detailed discussions and terms of agreement to protect all parties before the final decision was made. North Borneo and Sarawak in a joint note on 26 July 1962 took the same view that there must be a genuine willingness by the Malayans to treat the Borneo Territories differently from existing States of the Federation. Lew Kuan Yew was said to have bargained for negotiations in London for improvements in citizenship provisions through a 
reply to Tunku Abdul Rahman on 30 and 31 July 1962. Lee Kuan Yew has pledged to Singaporeans that the terms of citizenship agreement is a long-standing promise in the Voice of Singapore held on September 1, 1961 (Rozeman Abu Hassan, 2016: 190).

The date for the establishment of Malaysia was agreed on 31 August 1963 but had to be amended to 16 September 1963 to confirm whether the people of North Borneo and Sarawak really wanted to join Malaysia. The suspension was also due to a protest made against the United Nations Secretary-General (UN) on the Cobbold Commission report. Instead, Lee Kuan Yew declared August 31, 1963 as the date of independence for Singapore. Lee Kuan Yew's actions have resulted in a conflict in decision-making for Malaysia whereas both leaders have agreed in terms of the determined dates. Duncan Sandys admits that Lee Kuan Yew is a shameless person for exposing the date of deferment of Malaysia to achieve his personal aspirations (Rozeman Abu Hassan, 2016: 193).

The merger between Malaya, Sabah and Sarawak has indeed united all races and tribes, thus creating a very unique culture under one roof. This means that Malaysia has emerged as a rich country with unique and diversed cultures, customs, beliefs and lifestyles. As a result, Malaysia has successfully attracted tourists from around the world to experience for themselves the diversity of cultures. Practically it is very difficult to unite different people, culture and way of life. However, with the establishment of Malaysia, unity among its people was attained through plans by previous government leaders. Unity is fundamental to economic, political and social development of a country. Hence, the establishment of Malaysia has not only been able to unite the people but also to form an integrated nation called Malaysia (Hasnah Hussiin, 2017: 3).

\section{Politics}

It caught attention when the Federation of Malaya showed its interest in bringing Singapore into the Federation of Malaysia again. The British themselves agreed with this coalition as there are many similarities in terms of history, law, economy and finance between the two. Tunku Abdul Rahman is aware of this opportunity to provide an early independence for Singapore. In addition, many opinions mentioned Singapore as a small country will not be able to stand alone as it is surrounded by larger neighbours such as the Federation of Malaya and Indonesia.

The coalition with Singapore is important due to numerous political situations and its security is worth noting. The People's Action Party (PAP) under the leadership of Lee Kuan Yew who ruled Singapore at that time was in deterioration. This phenomenon is clear when PAP lost in the by-election in the Hong Lim area in May 1961 and then the Anson area in July of the same year. This is cause for concern not only as a result of the victory of Ong Eng Guan from the United People's Party (UPP) in Hong Lim and the Labor Party at Anson but also due to the influence of the left wing in the PAP itself. The group was split from the PAP and formed the Socialist Front.

If this situation is left unchecked, it is feared that the PAP government will lose out to the Socialist Front. This situation is disturbing for the Federation of Malaya because of its good relations with Singapore covering political and economic affairs and will be affected if the PAP is overthrown. The bigger concern is actually related to the influence of communist infiltration into the leftist group. The British and the Federation of Malaya certainly did not want the Singapore government to be taken over by the leaders of communist ideology. The British government had planned to accord independence to Singapore in mid-1963. If the elections were held during that period, the leftist party was 
found to have the potential to defeat the PAP and take over the government. This is what the Federation of Malaya does not want.

Earlier, the Federation of Malaya considered merging with Singapore was a dangerous act due to the support of communism in the state. However, after negotiations with the Prime Minister of Singapore and the British, it was found that letting Singapore tackle this issue on its own is more dangerous and costly. Therefore, the best way to curb this political phenomenon is to merge with Singapore. Economically, many argue that Singapore does not have enough economic resources. This makes it difficult for it to form a strong national economic system.

The Alliance Government considers merging not only with Singapore, but also with the British territories of Borneo, Sabah, Sarawak and Brunei as the best way to curb unhealthy political developments in Singapore. The active communist influence around the 1950s has also spread to Sarawak resulting in the establishment of the Overseas Chinese Democratic Youth League and the Sarawak Advanced Youth Association. Their movement has influenced and incited the Chinese comprising students and trade unions against the British. In addition, a relatively influential party in Sarawak, the Sarawak United People's Party (SUPP) has also been influenced by the communist ideology (Mardiana Nordin \& Hasnah Hussiin, 2006: 64-65).

Various political parties were formed in Sarawak before the establishment of the Federation of Malaysia in 1963. Initially, membership of political parties in Sarawak was multiracial. However, developments in the next decade show the direction of membership and struggle to racism. The SUPP, founded in 1959, is the oldest party in Sarawak. In the early stages of the establishment of SUPP is a multi-racial structure with 46 per cent of members comprised of bumiputeras. In 1962, SUPP led by Ong Kee Hui as chairman and Stephen Yong as the secretary general received encouragement from the colonial administration in preparation for the self-directed British rule (Shamsul Amri Baharuddin, 2012: 134)

Leaders in the Chinese-controlled SUPP and anti-Malays were increasingly unable to control the 'communist elements' in their party. There is a saying that 'after Malaysia when British control does not exist,' the local government will act 'very hard against the Communists.' In fact, Sarawak's first Chief Minister, Stephen Kalong Ningkan promises tough action against local radicals to be taken as soon as Malaysia is formed 'If my brother is a communist, I would have to arrest him.' For British companies in North Borneo, Brunei and Sarawak, Malaysia's block also provided a way of preventing the expansion of Indonesia's power with its unpredictable attitude, increasingly leftist in nature and wanting to expand its territory. Such a situation is evident especially after the rebellion in Brunei which was suppressed by the end of 1962. For J.P. Pearson, General Manager of BCL in Kuching, Indonesia's current influence on Borneo appears to be widespread. The Sukarno regime is suspected of training hard-core insurgents in Brunei; after the rebellion, 1,000 radical Sarawakians trained in Borneo Indonesia; communists from Kalimantan infiltrated into agricultural lands in the Tawau area in North Borneo; Indonesian propaganda broadcasting can be heard throughout the island; and in the last days of colonial rule, Sukarno intervened in the mission of the United Nations (UN) to evaluate the opinion of the Borneo population on unification with Malaysia. Therefore, at a lunch meeting with the Sarawak Chamber of Commerce in March 1962, Lord 'Kim' Cobbold, British chairman of the British-Malayan investigation commission in Borneo, was told that 'Malaysia is faster, it is better.' Kuala Lumpur's view, the political aspect in 'Malaysia Raya' also has a lot of charm. G.E. Jones in ICI (Malaya) Ltd voiced his views in April 1963, 'The unification of 
the five states in a political union will certainly bring stability to this region and this stability is necessary if trade is to be developed' (Nicholas J. White, 2010: 43)

In Sabah and Sarawak, there were many political parties representing their respective ethnicities, especially towards the formation of the Federation of Malaysia. Political development is heavily influenced by the pluralistic structure of the two countries. Through the process of political socialisation, members of political parties were from various ethnicities, participating in campaigns and pursuing political issues through the mass media. The politics of Sabah and Sarawak is more complex than in the Peninsula. Sabah and Sarawak adopted a political coalition to form the government since 1963 (Shamsul Amri Baharuddin, 2012: 130).

Parti Negara Sarawak (PANAS) led by Temenggung Jugah, Sarawak United People's Party or Sarawak United People's Party (SUPP) led by Ong Kee Hui and Sarawak National Party (SNAP) headed by Stephen Kalong this merger proposal. SUPP is open to various races, but the majority of its members are Chinese. SNAP consists of Iban people. The party that supports this proposal is Barisan Rakyat Jati Sarawak (BERJASA). In Sabah, the first political party in Sabah was born in August 1961 among the Kadazan people, the United Nations National Organization or United National Kadazan Organization (UNKO) led by Donald Stephens. In June 1962, the Murut of Sabah formed a party called Pasok Momogun National North Borneo led by G. S. Sundang. There is a Sabah political party that accepts Tunku Abdul Rahman's plan, the United Sabah National Organization (USNO). By late 1962 and early 1963, most of the population changed their minds after receiving more information on this plan. UNKO chairman, Donald Stephens, who once opposed gave strong support and persuaded the Kadazan community to accept the formation of Malaysia. Until the formation of Malaysia in 1963, SUPP was the only political party in Sarawak who objected to this proposal (Mardiana Nordin \& Hasnah Hussiin, 2018: 91-92).

\section{CONCLUSION}

In conclusion, the initial idea of uniting Malaya, Sabah, Sarawak, Brunei and Singapore as a nation has a long history. Finally, this idea was successfully realised on 16 September 1963 without Brunei's participation despite the early stages of support and consent. However, Singapore has seceded from the Federation of Malaysia in 1965 after two years being in the Federation of Malaysia. This separation is for preservation of Malaysia's safety and harmony. Tunku Abdul Rahman and Lee Kuan Yew signed an agreement on the separation of Singapore from the Federation of Malaysia as an independent and sovereign state. This event caused the Federal of Malaysia to be amended for the first time to allow Singapore to leave Malaysia and to be a free country. This amendment involves the Constitution and Malaysia Act (Singapore Amendment) Act 1965. Meanwhile, for the indigenous communities in Sabah dan Sarawak including the non-Malays, their position is recognised and protected by the Federal Constitution of Malaysia under Article 160 (2) similar to the Malays in the Peninsular. From the political aspect, political parties in Sabah dan Sarawak that are based on ethnicity and region continue to contribute to Malaysian politics to this day. Indeed, the establishment of Malaysia has given many benefits to Malaya, Sabah and Sarawak both politically, plurality and socio-economically.

\section{REFERENCES}

A Rahman Tang Abdullah et.al. (2017). 'Perjanjian Malaysia 1963 dan Soal Perundangan Sabah dan Sarawak: Tinjauan Terhadap Isu Sejarah dalam Laman Sosial.' Jurnal 
Komunikasi Borneo. http://jkob.cseap.edu.my/index.php/journal/full/edisi-khas-3-5.pdf. 85-103.

Ariffin Omar. "Dari Malayan Union ke 13 Mei" dalam Abdul Rahman Haji Ismail (ed.). Malaysia: Sejarah Kenegaraan dan Politik. (2007). Kuala Lumpur: Dewan Bahasa dan Pustaka.

Artikel Khas Sempena Sambutan Hari Malaysia yang ke-55 tahun. 'Kupasan Sejarah Perjanjian Malaysia 1963: Edisi September 2018.' Pejabat Perdana Menteri. https://www.pmo.gov.my/MA63.pdf. Retrieved on 8 Februari 2019.

Hasnah Hussiin. 27 Julai 2017. 'Manfaat Penubuhan Malaysia 16 September 1963.' Dalam http://hasnahhussiin.blogspot.com./2017/07/manfaat-penubuhan-malaysia-16september.html. Retrieved on 8 Februari 2019.

Kassim Thukiman. (2002). Malaysia: Perspektif, Sejarah dan Politik. Johor:Penerbit Universiti Teknologi Malaysia.

Mardiana Nordin \& Hasnah Hussiin. (2014). Pengajian Malaysia Edisi Kelima. Selangor: Oxford Fajar.

Mardiana Nordin \& Hasnah Hussiin. (2018). Pengajian Malaysia Edisi Keenam. Selangor: Oxford Fajar.

Nik Anuar Nik Mahmud. (2001). Duri Dalam Daging:Singapura Dalam Malaysia. Kuala Lumpur:Persatuan Sejarah Malaysia.

Rozeman Abu Hassan. (2016). Dasar British terhadap hubungan Singapura-Malaysia 1959-1969. Bangi: Penerbit Universiti Kebangsaan Malaysia.

Ruslan Zainuddin, Mohd Mahadee Ismail, Zaini Othman. (2005). Kenegaraan Malaysia. Selangor:Fajar Bakti Sdn. Bhd.

White Nicholas J. (penterjemah) Shakila Parween Yacob. (2010). Perniagaan British di Malaysia pascapenjajah, 1957-70: 'Neokolonialisme' atau 'pengunduran'?. Kuala Lumpur: Institut Terjemahan Negara Malaysia. 